\title{
An Improved Sensitive and Selective Non-enzymatic Glucose Biosensor Based on PEG Assisted CuO Nanocomposites
}

\author{
A. Mohamed Azharudeen ${ }^{1}$, T. Suriyakala ${ }^{1}$, M. Rajarajan ${ }^{2 *}$, A. Suganthi ${ }^{3}$ \\ ${ }^{1} P G$ and Research Department of Chemistry, C.P.A. College, BBodinayakanur - \\ 625513, Theni District, TamilNadu, India. \\ ${ }^{2}$ Directorate of Distance Education, Madurai Kamaraj University, Madurai-625021. \\ TamilNadu, India. \\ ${ }^{3}$ Mother Teresa Women's University, Kodaikanal - 624 102, Dindugal District. \\ TamilNadu, India.
}

D ETERMINATION of glucose is of enormous importance in the fields of biological, environmental and clinical analyses. In recent years, polymer modified metal oxides arrived a great consideration in the detection of glucose. In this study, we have developed a sensitive and selective non-enzymatic glucose sensor by using $\mathrm{CuO}$ NMO encapsulation with PEG (poly ethyleneglycol) nanocomposites. The loading content of PEG was incorporated with $\mathrm{CuO}$ by weight percentage $(\mathrm{wt}=2,4 \& 6 \%$ ). The fabricated $\mathrm{CuO} / \mathrm{PEG}$ nanocomposites were utilized as a glucose sensor, it exhibits the tremendous electrocatalytic performances on oxidation of glucose. The electrocatalytic activity enhances with increasing the loading of PEG content. The sensor shows a low detection limit of $0.25 \mu \mathrm{M}$ with a sensitivity of 113.8 $\mu \mathrm{A} \mathrm{mM}^{-1} \mathrm{~cm}^{-2}$, good selectivity and stability. The $\mathrm{CuO} / \mathrm{PEG}$ nanocomposites are hopeful for the advancement of cost-effective non-enzymatic glucose biosensors.

Keyword: $\mathrm{CuO}$, Mesoporous, PEG, Glucose, Biosensor.

\section{Introduction}

The enlargement of electrochemical glucose sensor has fascinated extensive awareness in many areas such biotechnology, clinical diagnostics and food industry [1-3]. Blood glucose observation is a mode of testing the concentration of glucose in the blood and particularly essential in the protection of diabetes. In the past, the investigation for the enzymatic glucose biosensors based on using glucose oxidase have been extensively employed in the glucose determination was very popular owing to their high sensitivity, selectivity and low detection limit [4-6]. Clark et al., [7] discovered enzyme based first electrode system for monitoring in cardiovascular surgery and afterwards there are numerous enzyme oriented electrode was designed. However, enzyme oriented glucose biosensors undergo several disadvantages such as inadequate stability originated from the thermal and chemical instability of enzymes, intricate immobilization route of enzyme, poor reproducibility, high cost and the oxygen limitation $[8,9]$.
To solve this trouble, numerous endeavours have been made to build up non-enzymatic glucose sensor. It is predominantly based on the glucose oxidation catalyzed by a multiplicity of electrocatalysts. The noble metals and metallic alloy are frequently utilized as catalytic materials for non-enzymatic glucose sensor. Among the noble metals, $\mathrm{Cu}$ and its oxides have gained an increasing awareness owing to their high electrocatalytic activity, low cost and anti-poisoning of chloridion, opportunity of promoting electron transfer reaction at a lower over potential [10,11]. For instance, Wang et al., synthesised $\mathrm{CuO}$ nanomaterials for the application of non-enzymatic glucose sensor [12]. Though, there are several attempts for preparing homogeneous nanoparticles and nanostructured metal oxides (NMOs) applied in the field of glucose sensor, due to their high oxidation potential, low sensitivity and fouling of the oxidation signals [13], the researchers travel to nanocomposites material for resolve these problems.

*Corresponding author e-mail: rajarajanchem1962@gmail.com; Phone: 0452 - 2459413; Fax: 0452-2458261 DOI: 10.21608/EJCHEM.2018.5707.1489

(C)2017 National Information and Documentation Center (NIDOC) 
In the production of nanocomposite materials, the polymer plays huge attention in electrochemical sensor because of unique properties of polymer such as compatibility, conductive nature, electron promoter and inexpensive $[14,15]$. The polymers such as poly (ethylene glycol) (PEG) [16], poly (vinyl pyrrolidone) (PVP) [17], poly vinyl alcohol (PVA) [18], poly acrylicacid (PAA) [19] and polyaniline (PANI) [20] are essentially used as binding mediator between the substrate and the glucose or a conductive substrate or as a adapted membrane for enhanced selectivity towards glucose [21]. It is well identified that, PEG has biocompatible lubricity and thermal stability. Hence, PEG was chosen as a capping or reducing agent in this work.

Besides, numerous researchers have been reported the preparation of nanocomposites using PEG as a surfactant/capping agent or modifier. Because, it is an economical organic stabilizer, simply soluble in water, need not difficult process, reactivity at relatively low temperature, non-toxic, non-irritating and moisturizing properties $[22,23]$. For instance, Reddy et al., [24] reported that, PEG modified $\mathrm{MoO}_{3}$ nanobelts through hydrothermal synthesis, Wolcott et al., [25] explored the interaction of PEG with $\mathrm{WO}_{3}$ and concluded the enhanced behaviour for PEG assisted nanoparticles in morphology, crystallanity and surface activity in addition to charge transport properties. Then, Wang et al., [26] reported that, one-step solid state reaction to the synthesis of copper oxide nanorods in the presence of a suitable surfactant (PEG), in this work the polymer PEG is used as a surfactant. Thus, previous reports obviously show that $\mathrm{CuO}$ based nanocomposites were rarely investigated to the development of glucose biosensor.

Here in, we report the preparation of $\mathrm{CuO}$ NMO via chemical precipitation method and incorporated with PEG. The fabricated $\mathrm{CuO} /$ PEG composites were applied as a highly reactive electrocatalyst for glucose oxidation. The sensor exhibits excellent performance such as high sensitivity, stability, low detection limit, good selectivity and cost effective.

\section{Experimental}

\section{Reagents}

$\mathrm{Cu}\left(\mathrm{NO}_{3}\right)_{2} \cdot 3 \mathrm{H}_{2} \mathrm{O}, \mathrm{NaOH}$, glucose, ethanol and $\mathrm{PEG}$ of analytical grade and purchased from Merck, India and were used without additional purification. All solutions were recently prepared with double distilled (DD) water.

Egypt.J.Chem. 62, No. 3 (2019)

\section{Synthesis of copper oxide}

About $2.4 \mathrm{~g}$ of copper nitrate trihydrate $(0.1$ $\mathrm{M})$ is dissolved in $100 \mathrm{~mL}$ of DD water and $0.8 \mathrm{~g}$ of $\mathrm{NaOH}(0.2 \mathrm{M})$ is dissolved in $100 \mathrm{~mL}$ of DD water, separately. The copper nitrate trihydrate solution was taken in a RB flask and $\mathrm{NaOH}$ solution is added slowly drop by drop to the above solution under continuous magnetic stirring for 2 hrs. The precipitate is then filtered off and heated in a hot air oven at $120{ }^{\circ} \mathrm{C}$ for $1 \mathrm{hr}$. The product is finely crushed and calcinated at $500^{\circ} \mathrm{C}$ for $2 \mathrm{hrs}$ in a muffle furnace. The product obtained was black in colour.

Preparation of PEGmodified CuOnanocomposites

The polymer modified copper oxide is prepared by immersion method. $2 \mathrm{~g}$ of earlier synthesized $\mathrm{CuO}$ in $100 \mathrm{~mL}$ of ethanol was immersed with $2 \%$ of PEG in ethanol using ultrasonication for 1 hr. After 12 hrs stirring the solvent is evaporated and product was dried at $80^{\circ} \mathrm{C}$ followed by a heat treatment at $160^{\circ} \mathrm{C}$ in a hot air oven for $2 \mathrm{hrs}$. Similarly, 4\% of PEG and 6\% of PEG in ethanol was immersed with $\mathrm{CuO}$ NMO successively.

\section{Preparation of modified CuO/PEG/GCE biosensor}

Preceding to use, the glassy carbon (GC) electrode was carefully polished with polishing paper and 1.0, 0.3 and $0.05 \mathrm{~mm}$ alumina slurry consecutively then dried in air after that sonicated in DD water followed by ethanol meticulously. The electrode was sonicated for $10 \mathrm{~min}$ to remove the adsorbed alumina particles on the surface of the $\mathrm{GC}$ electrode. Then the electrode was washed with ethanol and subsequently with DD water and the $6 \mathrm{mg}$ of synthesized $\mathrm{CuO} / 2 \% \mathrm{PEG}$ was dispersed with DD water $(3 \mathrm{~mL})$ and ethanol $(2 \mathrm{~mL})$ using ultrasonically dispersion. Then approximately $5 \mu \mathrm{L}$ of dispersion was dipped onto the clean GC electrode and dried at room temperature. The modified $\mathrm{CuO} / 2 \% \mathrm{PEG}(\mathrm{C} 2 \mathrm{P}) / \mathrm{GC}$ electrode was attained. Similarly, the $\mathrm{CuO} / 4 \% \mathrm{PEG}(\mathrm{C} 4 \mathrm{P}) /$ GC modified electrode, $\mathrm{CuO} / 6 \% \mathrm{PEG}(\mathrm{C} 6 \mathrm{P}) / \mathrm{GC}$ modified electrode, $\mathrm{CuO} / \mathrm{GC}$ modified electrode and $\mathrm{PEG} / \mathrm{GC}$ modified electrode were also obtained successively.

\section{Characterization}

The absorption of synthesized nanocomposites are determined by using JASCO V-750 spectrophotometer, the functional group was predicted by JASCO FT/IR-4200 FourierTransform spectrophotometer. The crystalline structure of synthesised nanomaterial was 
confirmed by Analytical XPERT PRO X-ray diffractometer with $\mathrm{Cu} \mathrm{K} \alpha$ radiation of wavelength 1.541. The SEM \& EDX results of synthesized nanocomposites are analyzed by JOEL model JSM 6701FSEM. The HR-TEM \& SEAD images attained from JOEL model 3010 microscope. The surface area is measured by micromatrics, ASAP 2020 B.E.T instrument.

Electrochemical experiments of synthesised nanomaterials $\mathrm{CuO}, \mathrm{C} 2 \mathrm{P}, \mathrm{C} 4 \mathrm{P}$ and $\mathrm{C} 6 \mathrm{P}$ were performed with a CHI608D electrochemical workstation (CHI, USA). A standard three electrode cell was employed for the electrochemical tests. A 3-mm diameter GC was used as the working electrode (a working area of around $0.07 \mathrm{~cm}^{2}$ ). A silver/silver chloride $(\mathrm{Ag} / \mathrm{AgCl})$ electrode and a platinum electrode were utilized as the reference and the counter electrodes, respectively. All potentials in this examine are accounted with respect to the $\mathrm{Ag} /$ $\mathrm{AgCl}$ electrode. The measurements were carried out in a $0.1 \mathrm{M} \mathrm{NaOH}$ solution on a $\mathrm{pH}$ of 12 at room temperature.

\section{Results and Discussion}

\section{$U V$-vis-DRS}

The optical property is very important in the field of electrocatalytic activity. The UV-vis-DRS of $\mathrm{CuO}, \mathrm{C} 2 \mathrm{P}, \mathrm{C} 4 \mathrm{P}$ and $\mathrm{C} 6 \mathrm{P}$ nanocomposites are shown in Fig. 1. The absorption edge of $\mathrm{CuO}$ found at $360.08 \mathrm{~nm}$, whereas, the polymer modified composites $\mathrm{C} 2 \mathrm{P}, \mathrm{C} 4 \mathrm{P}$ and $\mathrm{C} 6 \mathrm{P}$ were existed at $361.84,362.01$ and $364.75 \mathrm{~nm}$ respectively. The $\mathrm{CuO} \mathrm{NMO}$ was compared with the $\mathrm{C} 2 \mathrm{P}, \mathrm{C} 4 \mathrm{P}$ and $\mathrm{C} 6 \mathrm{P}$ are slightly red shifted from 360.08 to $361.84,362.01$ and $364.75 \mathrm{~nm}$ respectively.

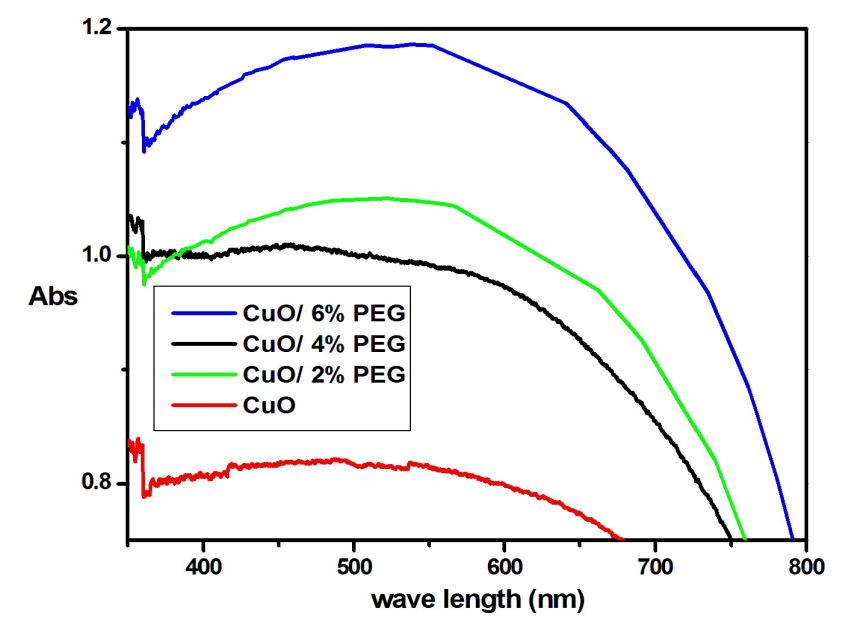

Fig. 1. UV- vis DR spectrum of $\mathrm{CuO}, \mathrm{C} 2 \mathrm{P}, \mathrm{C} 4 \mathrm{P}$ and $\mathrm{C} 6 \mathrm{P}$ nanocomposites.

This observed red shift is revealed that the electron transfer process is taking place in composite materials. The polymer enhances the electron transfer from valance band to conduction band by overlapping or capping on surface of the $\mathrm{CuO}$ This red shift leads to the increase in grain size and electro active sites of synthesized nanocomposites of C2P, C4P and C6P, while increase in PEG content. Among, the synthesized composite C6P having high in shift. Therefore, high in granular size, more effective area and high electrocatalytic activity. The energy band gaps of $\mathrm{CuO}, \mathrm{C} 2 \mathrm{P}, \mathrm{C} 4 \mathrm{P}$ and $\mathrm{C} 6 \mathrm{P}$ were determined by using Tauc's equation (1).

$$
\alpha=\frac{C\left(h v-E_{g} b u l k\right)^{2}}{h v}
$$

Where $\alpha, C, h v$ and $E_{g}^{b u l k}$ are absorption coefficient, constant, photon energy and band gap, respectively. Tauc's plots of $\mathrm{CuO}, \mathrm{C} 2 \mathrm{P}$, $\mathrm{C} 4 \mathrm{P}$ and $\mathrm{C} 6 \mathrm{P}$ are given in Fig. 2. The optical band gaps are 3.42, 3.34, 2.94 and $1.42 \mathrm{eV}$ for $\mathrm{CuO}, \mathrm{C} 2 \mathrm{P}, \mathrm{C} 4 \mathrm{P}$ and $\mathrm{C} 6 \mathrm{P}$, respectively. It is found that, the loading of PEG was increased with decreasing the band gap energy $\left(\mathrm{E}_{\mathrm{g})}\right.$. This may be due to the increase of oxygen deficiency while increase the PEG concentration without changing the concentration of $\mathrm{CuO}$. This specified that the PEG embraced samples have more optical conductivity than the surfactant free sample. 


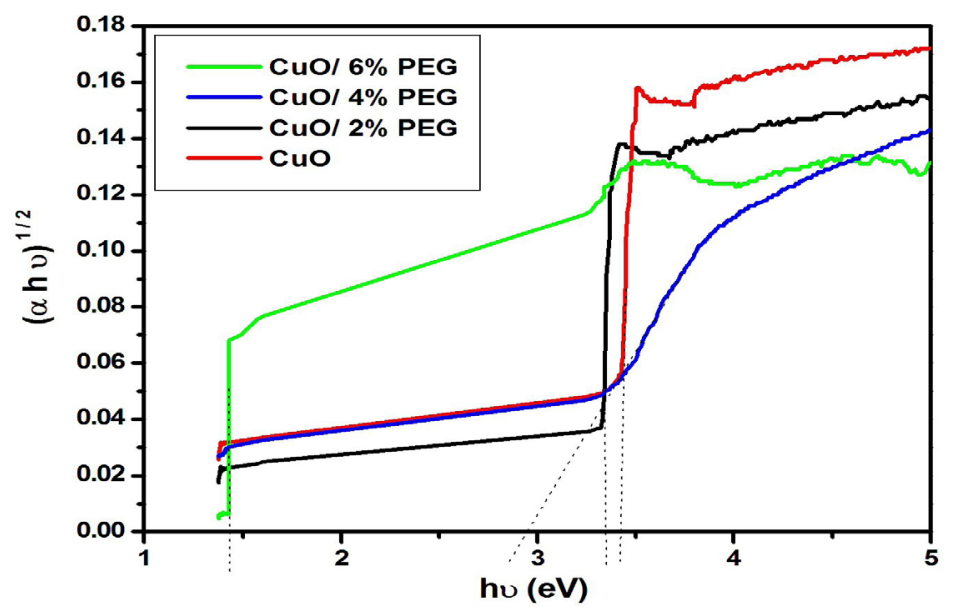

Fig. 2. Tauc's plot of C, C2P, C4P and C6P nanocomposites.

Fourier-Transform Infrared (FT-IR)

The FT-IR spectrum of prepared $\mathrm{CuO}, \mathrm{C} 2 \mathrm{P}$, C4P and C6P nanocomposites are shown in Fig. 3 (a-d). The characteristic peak of $610.45,614.61$, 619.22 and $627.74 \mathrm{~cm}^{-1}$ in the spectrum of $\mathrm{CuO}$, $\mathrm{C} 2 \mathrm{P}, \mathrm{C} 4 \mathrm{P}$ and $\mathrm{C} 6 \mathrm{P}$ shows the bending vibration of the $\mathrm{CuO}$ crystal lattice [27]. The spectrum of $\mathrm{C} 2 \mathrm{P}$, $\mathrm{C} 4 \mathrm{P}$ and $\mathrm{C} 6 \mathrm{P}$ nanocomposites were compared with $\mathrm{CuO} \mathrm{NMO}$, the wave numbers shifted from 610.45 to $627.74 \mathrm{~cm}^{-1}$. This shift demonstrates that, the presence of $\mathrm{CuO}$ in the PEG matrix. Further, the peaks appeared at 445.60, 452.67, 508.10 and $526.01 \mathrm{~cm}^{-1}$ of $\mathrm{CuO}, \mathrm{C} 2 \mathrm{P}, \mathrm{C} 4 \mathrm{P}$ and $\mathrm{C} 6 \mathrm{P}$ respectively, belongs to the $\mathrm{Cu}-\mathrm{O}$ deformation vibration. The absorption band at $1388.20 \mathrm{~cm}^{-1}$ for the sample of C6P (Fig. 3d) spectra corresponds to the bending vibration of methylene $\left(-\mathrm{CH}_{2}\right)$ while the loading of PEG is high (6\%), and this result suggested that some PEG molecules absorb on the surface on the $\mathrm{CuO} \mathrm{NMO}$, when increasing the loading of PEG. But, in case of $\mathrm{C} 2 \mathrm{P}$ and $\mathrm{C} 4 \mathrm{P}$ spectrum there is no absorption peak in the range of 1380 to $1395 \mathrm{~cm}^{-1}$. Since, low level loading of polymer (PEG) leads to the poor interaction between $\mathrm{CuO} \mathrm{NMO}$.

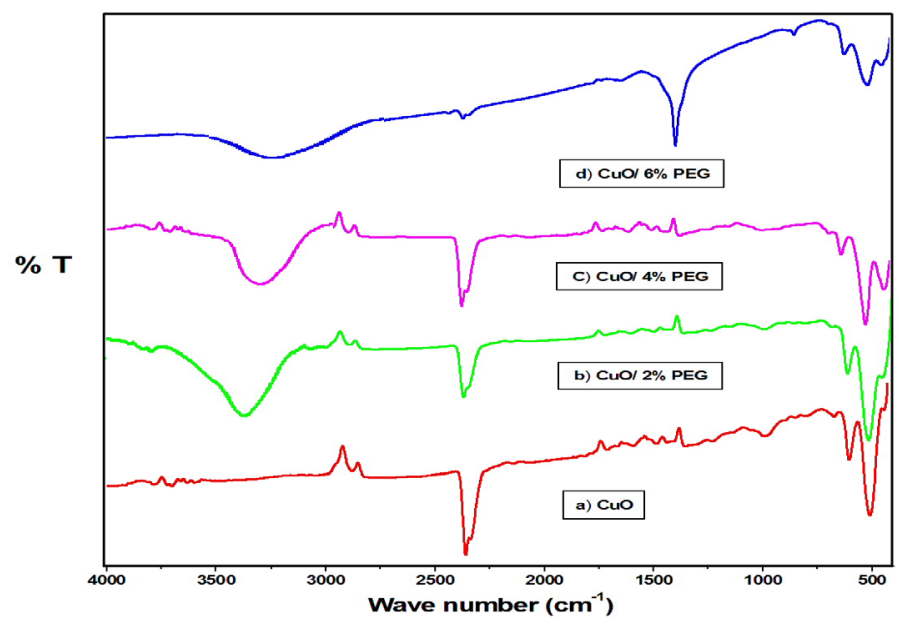

Fig. 3. FT-IR spectrum of (a) C, (b) C2P, (c) C4P and (d) C6P nanocomposites. 
The broad peak at 3379.43, 3309.71 and $3253.90 \mathrm{~cm}^{-1}$ corresponds to the stretching mode of- $\mathrm{OH}$ group of $\mathrm{CuO}$ capped $\mathrm{PEG}$ named as $\mathrm{C} 2 \mathrm{P}$, $\mathrm{C} 4 \mathrm{P}$ and C6P. Once again, this shift reveals that the formation of inter molecular hydrogen bonds by the $-\mathrm{OH}$ of PEG on the surface of $\mathrm{CuO} \mathrm{NMO}$ [28], thereby confirming the capping of PEG on $\mathrm{CuO}$ NMO. Here, the wave number decreases while the concentration of PEG increases onto the $\mathrm{CuO}$ NMO. Hence, the PEG encapsulate on the surface of CuO NMO.

\section{$X$-Ray Diffraction (XRD)}

The X-ray diffraction patterns of $\mathrm{CuO}$ and after loading of PEG different content of $\mathrm{C} 2 \mathrm{P}$, C4P and C6P were shown in Fig. 4 (a-d). The XRD pattern of $\mathrm{CuO}$ (Fig. 4a) is compared with all polymer modified nanocomposites such as C2P, C4P and C6P can keep the typical $\mathrm{CuO}$ crystal structure after $\mathrm{CuO} \mathrm{NMO}$ are incorporated into the PEG. In contrast with the standard diffraction patterns for C (JCPDS NO.
41-0254). Meanwhile no other diffraction peaks for impurities are detected. The diffraction peaks attain at $2 \theta$ values of $32.52^{\circ}, 35.51^{\circ}, 38.93^{\circ}$, $46.38^{\circ}, 48.75^{\circ}, 53.51^{\circ}, 58.37^{\circ}, 61.65^{\circ}, 66.32^{\circ}$, $67.87^{\circ}, 72.44^{\circ}$ and $74.89^{\circ}$, corresponding to (110), (-111), (200), (-112), (-202), (020), (202), (-113), (-311), (113), (311) and (004), respectively, can be indexed to the monoclinic phase of $\mathrm{CuO}$ [29] with lattice constants $\mathrm{a}=4.685 \AA, \mathrm{b}=3.423 \AA$ and $\mathrm{c}=5.132 \AA$. The XRD patterns also illustrated that, the intercalation of PEG does not vary the crystal structure of monoclinic $\mathrm{CuO}$ NMO. When the loading content of PEG was increased with decreasing in the intensity of diffraction peaks. This renders that incorporation of PEG on the surface of $\mathrm{CuO}$ NMO. The sharp diffraction peaks indicate excellent crystal structure of prepared $\mathrm{CuO}$ NMO. The average crystallite size is determined by Scherrer's formula given in below (eq. 2)

$$
\mathrm{D}=\frac{\mathrm{K} \lambda}{\beta \cos \theta}
$$

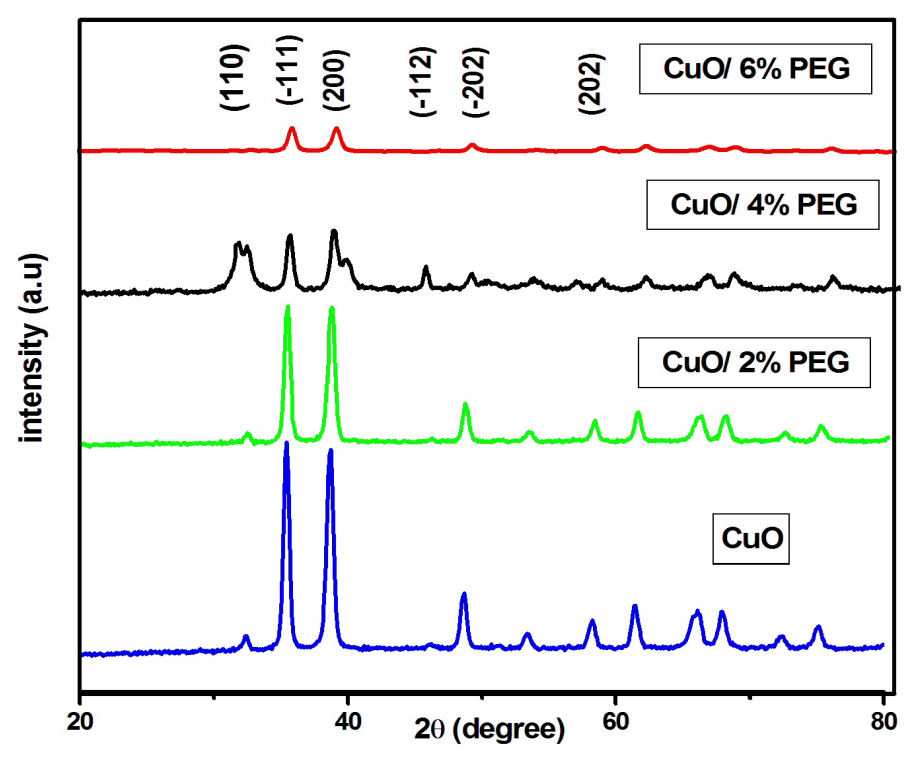

Fig. 4. XRD pattern of (a) C, (b) C2P, (c) C4P and (d) C6P nanocomposites.

Where $D$ is the average crystallite size, $\beta$ is the full width half maximum (FWHM) of the $2 \theta$ peak. $K$ is the shape of factor of the particles (it equals to 0.89 ), $\theta$ and $\lambda$ are the incident of angle and wavelength of the X-rays. The crystallite sizes were determined as $10.79,12.08,14.83$ and 44.94 $\mathrm{nm}$ for $\mathrm{CuO}, \mathrm{C} 2 \mathrm{P}, \mathrm{C} 4 \mathrm{P}$ and $\mathrm{C} 6 \mathrm{P}$, respectively. This result reveals that, there is a change in crystallite size. Obviously, this shows the capping effect of PEG on CuONMO.
Surface morphology and micro structure

The surface morphology of synthesized nanomaterials $\mathrm{CuO}, \mathrm{C} 2 \mathrm{P}, \mathrm{C} 4 \mathrm{P}$ and $\mathrm{C} 6 \mathrm{P}$ are characterized by SEM and exhibited in Fig. 5 (ad). The $\mathrm{CuO} \mathrm{NMO}$ (Fig. 5a) possesses irregular rod as well as sphere like structure and the surface is rough. However, after loading of PEG the $\mathrm{C} 2 \mathrm{P}$ nanocomposites (Fig. 5b) the surface morphology became needle like structure. The nanocomposites of C4P(Fig. 5c) resembled with nanorod and nanoflakes

Egypt.J.Chem. 62, No. 3 (2019) 
with smooth surface and the C6P nanocomposites (Fig. 5d) revealed that, the nanorod and nanoflake like structure with bigger in diameter derived from $\mathrm{CuONMO}$, illustrating the polymerization of the poly ethylene glycol (PEG) takes place on the surface of the $\mathrm{CuO}$ NMO. This image is depicted in Fig. 5 (d). The HR-TEM images of C6P nanocomposites (Fig. 6 a-c) show petal like structure and good dispersion of the nanoparticles within the polymer matrix of PEG. Figure 6 (d) displayed the selected area diffraction pattern (SAED), it shows the crystallinity of C6P nanocomposites.
The existence of $\mathrm{Cu}$ and $\mathrm{O}$ was confirmed by EDX and the results are given in Fig. 7 (a-d). The EDX results confirm the presence of $\mathrm{Cu}$ and $\mathrm{O}$. The peaks relevant to $\mathrm{Cu}$ and $\mathrm{O}$ are apparently observed at their normal energy. The EDX spectral data indicates obviously the formation of $\mathrm{CuO} \mathrm{NMO}$. It is found that, the intensity of the $\mathrm{Cu}$ in the EDX spectrum of $\mathrm{CuO}$ is 1464 increases to 1628,2473 and 2743 for the EDX spectrum of C2P, C4P and C6P nanocomposites respectively, while the PEG content is increasing. This confirms the polymer PEG exists on the surface of the $\mathrm{CuO}$ NMO.

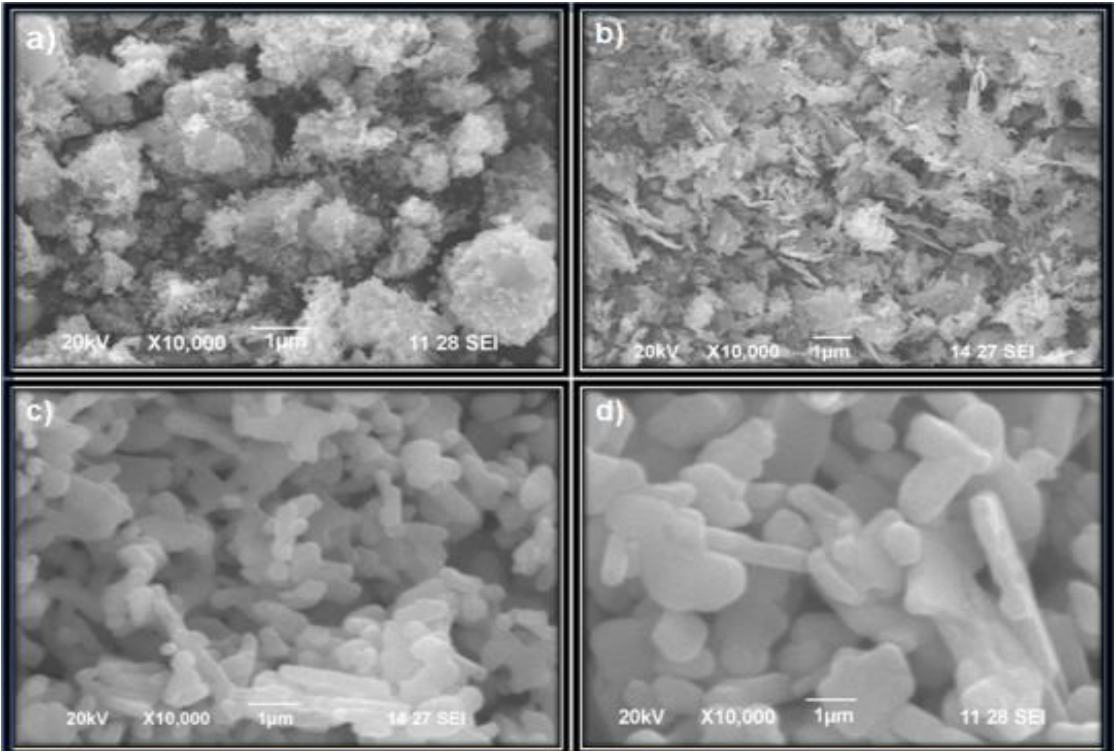

Fig. 5. SEM images of (a) C, (b) C2P, (c) C4P and (d) C6P nanocomposites.

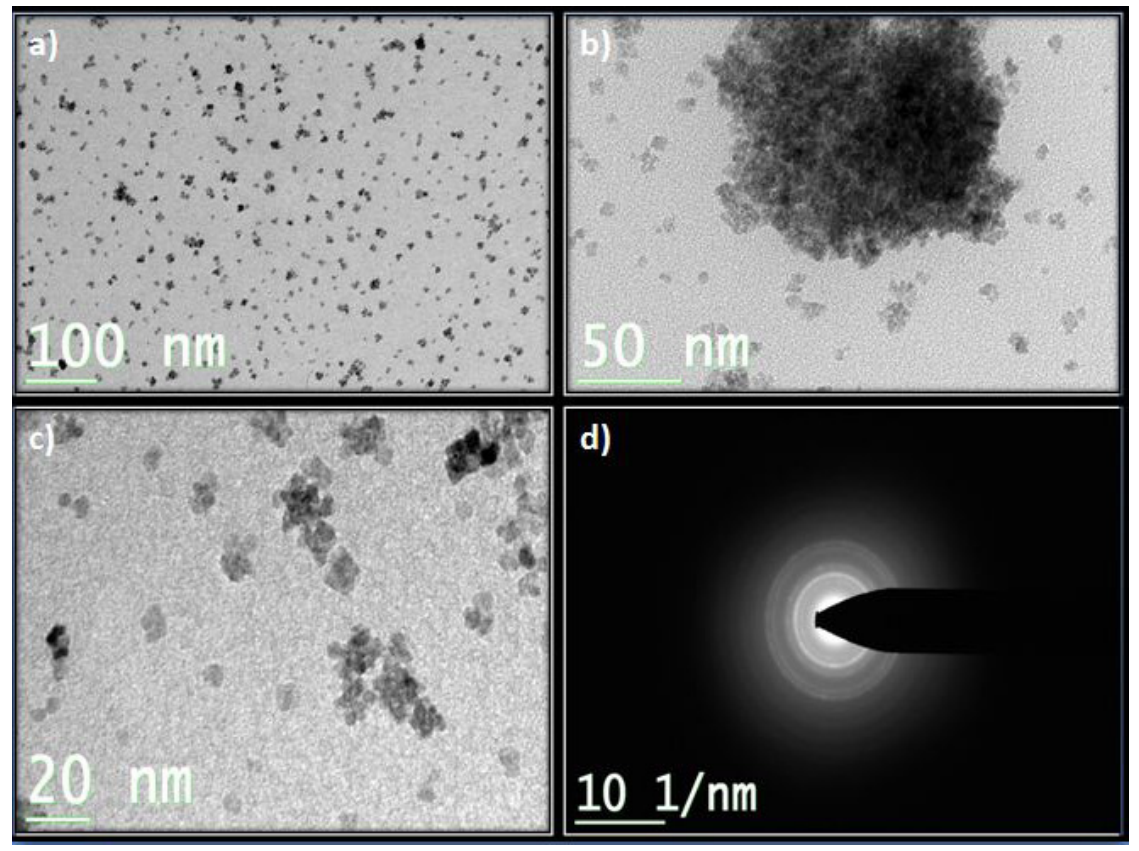

Fig. 6. HR-TEM (a-c) \& SEAD (d) images of C6P nanocomposites.

Egypt.J.Chem. 62, No. 3 (2019) 


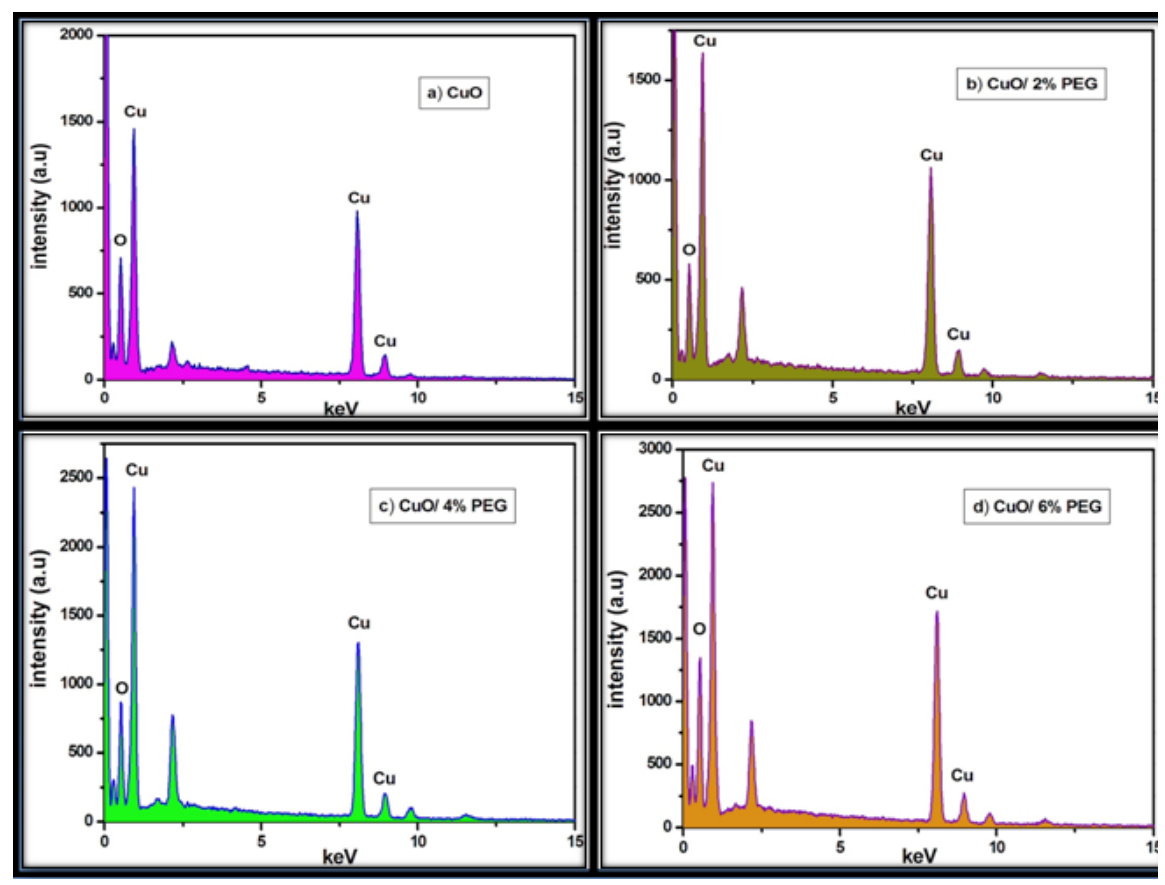

Fig. 7. The EDX spectrum of (a) C, (b) C2P, (c) C4P and (d) C6P nanocomposites.

Brunauer-Emmett-Teller (BET) adsorptiondesorption isotherm

$\mathrm{N}_{2}$ adsorption-desorption analysis is used to evaluate pore structures and surface area of $\mathrm{CuO}$ before and after loading of PEG based on the BET method. Figure 8 (a-d) is displayed the $\mathrm{N}_{2}$ adsorption-desorption curves of $\mathrm{CuO}, \mathrm{C} 2 \mathrm{P}, \mathrm{C} 4 \mathrm{P}$ and $\mathrm{C} 6 \mathrm{P}$, respectively measured at $77 \mathrm{~K}$. The surface areas were found to be 5.72, 16.39, 33.92 and 57.34 $\mathrm{m}^{2} / \mathrm{g}$ for $\mathrm{CuO}, \mathrm{C} 2 \mathrm{P}, \mathrm{C} 4 \mathrm{P}$ and $\mathrm{C} 6 \mathrm{P}$ respectively. The $\mathrm{N}_{2}$ adsorption-desorption curves of $\mathrm{CuO}$ (Fig. 8a) is compared with, the $\mathrm{C} 2 \mathrm{P}$ (Fig. 8b) and C4P (Fig. 8c) obeys the reversible type-III adsorption isotherm including $\mathrm{CuO}$. Here, the interaction (adsorptiveadsorbent) between $\mathrm{N}_{2}$ gas on $\mathrm{CuO}, \mathrm{C} 2 \mathrm{P}$ and $\mathrm{C} 4 \mathrm{P}$ are weak. However, this type of isotherms is not common, because, the small pore of $\mathrm{CuO}$, C2P and C4P does not fill with the adsorbate $\mathrm{N}_{2}$ gas. These are typical features of non-porous and macroporus materials. However, the C6P (Fig. 8d), the adsorption isotherm obviously followed type-IV and exhibits distinct hyderesis loop and indicating mesoporous. This type of isotherm taking place in mesopores materials. The adsorbent C6P have large surface area having more active sites, it allows the adsorbate $\mathrm{N}_{2}$ gas on its surface area in complete pore filling [30], while the loading of PEG is increased to $6 \%$. The polymer PEG plays a major role, it acts as a mesoporous medium to allow a guest molecule on its surface.
Among, the prepared nanocomposite C6P having more surface area and active-sites supplied by the polymer PEG, it might have large sensing activity. The sensitivity of the nanocomposites attributed to the nature of polymer, which serve as a matrix to oxidize the glucose molecule.

\section{Electrochemical performance of modified electrodes}

The modified electrode was characterized by cyclic voltammetry $(\mathrm{CV})$ between the potential of -0.4 to $0.7 \mathrm{~V}$ in $0.1 \mathrm{M} \mathrm{NaOH}$ solution at 50 $\mathrm{mV} \mathrm{s}^{-1}$ scan rate. The cyclic voltammogram of $\mathrm{CuO}$ shows in Fig. 9. The anodic peak current of $\mathrm{CuO}$ is appeared at $0.5 \mu \mathrm{A}$. This is owing to the electrocatalytic oxidation process in the alkaline electrolyte at the $\mathrm{CuO}$ electrode is generally considered as the following step:

The $\mathrm{CuO}$ is electrochemically oxidized to strong oxidizing $\mathrm{Cu}$ (III) species that is $\mathrm{CuOOH}$ is formed.

The other electrodes, such as PEG/GC electrode, $\mathrm{C} 2 \mathrm{P} / \mathrm{GC}$ electrode, $\mathrm{C} 4 \mathrm{P} / \mathrm{GC}$ electrode and $\mathrm{C} 6 \mathrm{P} / \mathrm{GC}$ electrode were conducted in $0.1 \mathrm{M} \mathrm{NaOH}$ solution at $50 \mathrm{mV} \mathrm{s}^{-1}$ scan rate. As shown in Fig. 9(a) no redox peaks can be observed at the GC electrode and PEG modified GC electrode. However, increase in current can be observed at around $0.4 \mathrm{~V}(\mathrm{vs} \mathrm{Ag} / \mathrm{AgCl})$ on the anodic peak current of $1.05,1.24$ and $1.89 \mu \mathrm{A}$ for $\mathrm{C} 2 \mathrm{P} / \mathrm{GC}$ electrode, Egypt.J.Chem. 62, No. 3 (2019) 
C4P/GC electrode and C6P/GC electrode, respectively. Among these results, the $\mathrm{C} 6 \mathrm{P} / \mathrm{GC}$ electrode has higher capacitance than the others. This indicate that the $\mathrm{CuO}$ have greatly improved the performance of the electrode and increased the electrocatalytic ability by increasing the loading content of PEG towards glucose oxidation, which may also be ascribed to their large surface area, active sites and enhanced the electron transfer rather than other electrodes.

\section{Effect of glucose concentration}

Furthermore, we used the same C6P/GCE to detect glucose molecule with various concentrations between 2 to $12 \mathrm{mM}$ glucose in $0.1 \mathrm{M} \mathrm{NaOH}$ medium at the scan rate of $25 \mathrm{mV} \mathrm{s}^{-1}$. As shown in Fig. 9 (b), the oxidation current can be found between 0.30 and $0.6 \mathrm{~V}$. The anodic peak is altered to the high potential region while the glucose concentration is increased. For the detection of 12 $\mathrm{mM}$ glucose, the peak current of a C6P modified $\mathrm{GC}$ electrode can reach $2.55 \mu \mathrm{A}$. However, the peak current for $14 \mathrm{mM}$ glucose is lower than $12 \mathrm{mM}$ glucose. Because, there is a degradation or fatigue occurrence for repetitive measurements using the same one electrode. The electrocatalytic oxidation process of glucose molecule by modified GCE in alkaline electrolyte undergoing several steps:

The glucose is catalytically oxidized by the $\mathrm{Cu}(\mathrm{III})$ species and produces gluconic acid.

\section{Effect of Scan rate}

The influence of scan rate on glucose oxidation at the $\mathrm{C} 6 \mathrm{P} / \mathrm{GC}$ modified electrode was also investigated in $0.1 \mathrm{mM}$ glucose for the understanding of the oxidation process. Figure $9(\mathrm{c})$ reveals that the $\mathrm{CV}$ of $\mathrm{C} 6 \mathrm{P} / \mathrm{GC}$ electrode in the range of $5-50 \mathrm{mV} \mathrm{s}^{-1}$. The oxidation peak current increased progressively with increasing the scan rate. As shown in the inset of Fig. 9 (c) linear response with the peak current $\left(I_{\mathrm{pa}}\right)$ and the scan rate $(v)$ with a correlation coefficient $\left(\mathrm{R}^{2}\right)$ of 0.9964 . The linear regression equation is expressed as $I_{\mathrm{pa}}(\mu \mathrm{A})=2.33+4.06 \nu\left(\mathrm{mV} \mathrm{s}^{-1}\right)$. This result verifies that the electrochemical oxidation of glucose is controlled by surface adsorption of glucose molecule.

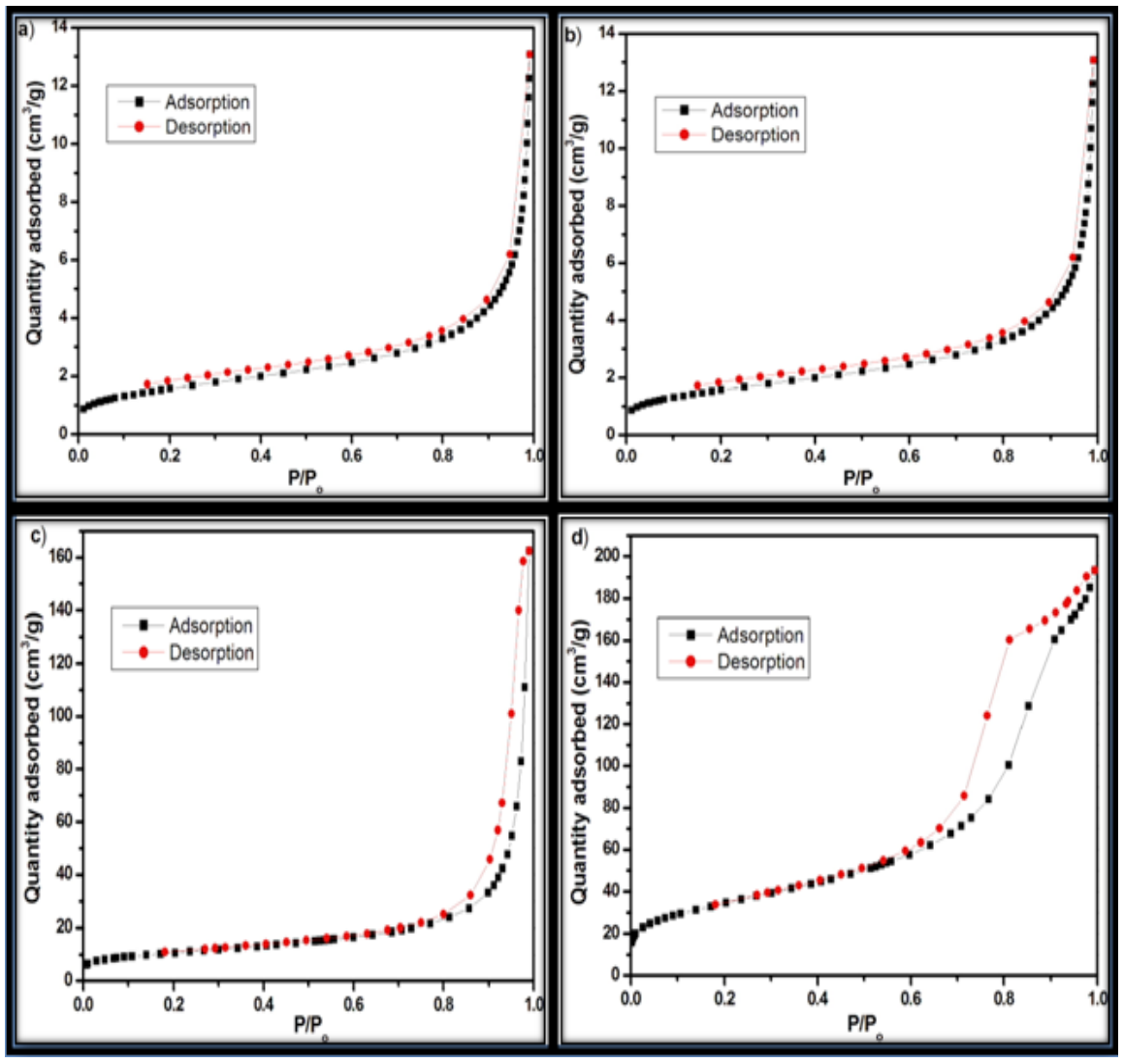

Fig. 8. N2 adsorption-desorption isotherm for (a) C, (b) C2P, (c) C4P and (d) C6P nanocomposites 


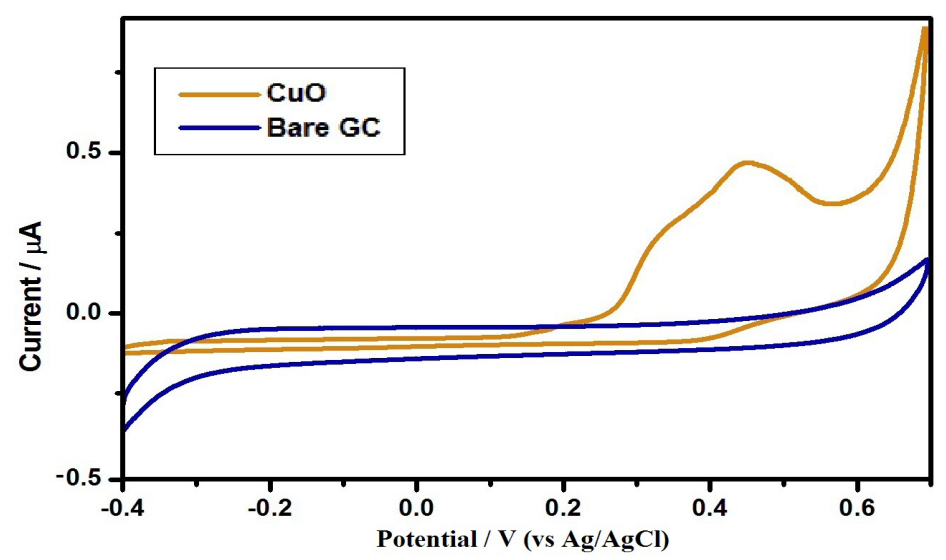

Fig. 9. $\mathrm{CV}$ curve of $\mathrm{CuO}$ modified GCE in $0.1 \mathrm{M}$ of $\mathrm{NaOH}$ solution at the scan rate of $50 \mathrm{mVs}-1$.

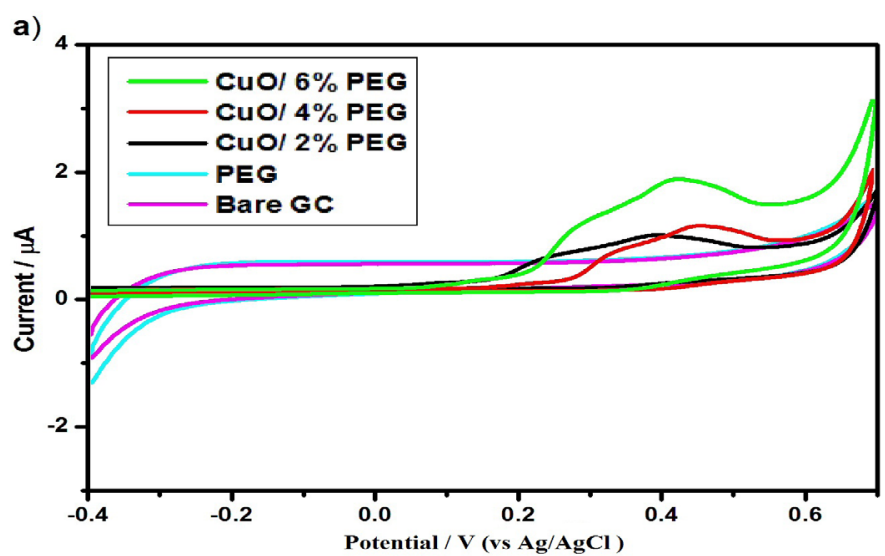

Fig. 9 (a). CV curves of PEG, C2P, C4P and C6P modified GCEs in $0.1 \mathrm{M}$ of $\mathrm{NaOH}$ solution at the scan rate of $50 \mathrm{mVs}-1$.

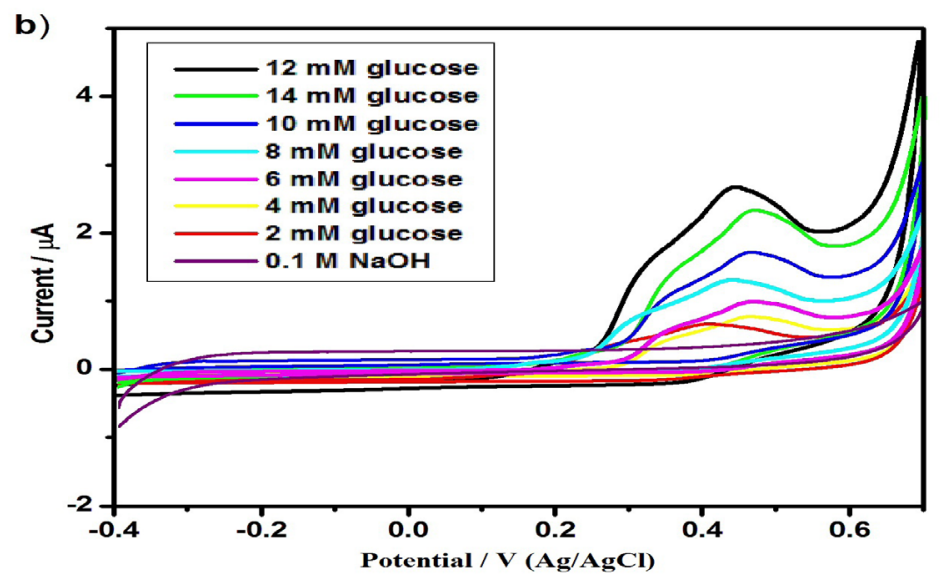

Fig. 9 (b). CV curves of C6P modified GCE under various glucose concentration in $0.1 \mathrm{M}$ of $\mathrm{NaOH}$ solution at the scan rate of $25 \mathrm{mVs}-1$. 


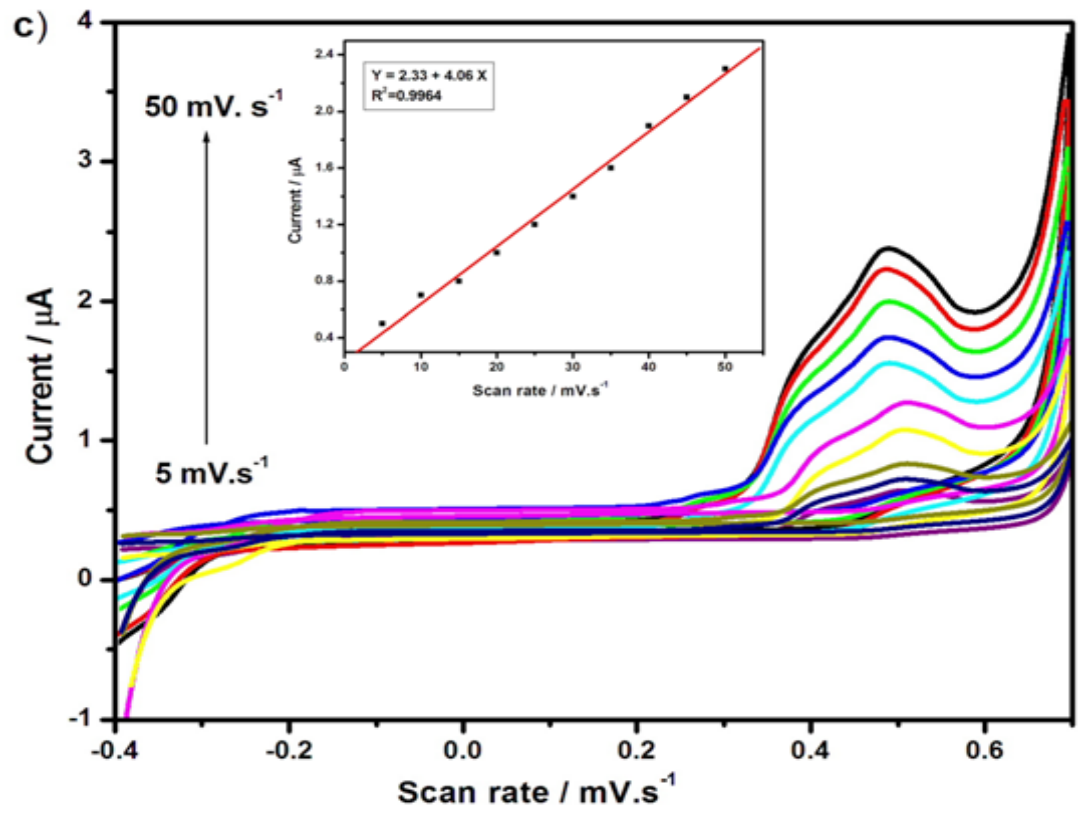

Fig. 9 (c). Give to supporting CV of $5 \mathrm{mM}$ glucose at the different scan rate. Inset: The plot of anodic peak currents vs. Scan rates.

Amperometric detection of glucose at C6P/GCE

Amperometry was utilized to ascertain the detection of glucose. The $0.1 \mathrm{M} \mathrm{NaOH}$ was used as the supporting solution with the injection of $2 \mu \mathrm{M}$ glucose every $25 \mathrm{~s}$. The potential was set as $+0.4 \mathrm{~V}$ (vs. $\mathrm{Ag} / \mathrm{AgCl}$ ) since, in Fig. 9 (b) the current response of $\mathrm{C} 6 \mathrm{P}$ increased gradually from +0.4 to +0.6 V. From Fig. 9 (b) the anodic peak current exists between $+0.4 \mathrm{~V}$ to $+0.6 \mathrm{~V}$. The optimum applied potential may be present in the range of +0.4 to $+0.6 \mathrm{~V}$. But, the potential of +0.4 was 1 fold larger than $+0.3 \mathrm{~V}$ and 2 fold smaller than $+0.6 \mathrm{~V}$. Therefore, the applied potential was fixed as $+0.40 \mathrm{~V}$ and the result shown in Fig. 10 . From the amperometric curve of glucose, the current increases gradually. The linear relationship between the oxidation current and the glucose concentration was obtained for concentrations ranging from $2 \mu \mathrm{M}$ to $18 \mu \mathrm{M}$. Figure 11 showed that, the amperometric response of each addition of $20,40,60,80$ and $100 \mu \mathrm{M}$. The insets of Fig. 10 and 12 show the corresponding calibration curve of the sensor. The linear equations $I_{p a}(\mathrm{~A})=5.00$ $+2.73 \mathrm{C}_{\text {glucose }}$ and $I_{p a}(\mathrm{~A})=3.59-4.41 \mathrm{C}_{\text {glucose }}$ with correlation coefficient $\left(\mathrm{R}^{2}\right)$ of 0.9912 and 0.9976 was obtained, respectively. Under the optimal conditions the sensor shows a low detection limit $(\mathrm{S} / \mathrm{N}=3)$ of $0.25 \mu \mathrm{M}$ with a sensitivity of 113.8 $\mu \mathrm{A} \mathrm{mM} \mathrm{m}^{-1} \mathrm{~cm}^{-2}$. This high level of the sensitivity is mainly attributed to the electrocatalytic activity of $\mathrm{CuO}$ with the enhancement effect of polymer

Egypt.J.Chem. 62, No. 3 (2019)
PEG, which acts as a network to oxidize the glucose molecule.

\section{Interference Analysis}

It is well known that some simply oxidative species such as fructose, sucrose, uric acid (UA) and ascorbic acid (AA) frequently co-exist with glucose in human blood [32]. Thus, the electrochemical reply of the interfering species also examined at the $\mathrm{C} 6 \mathrm{P} / \mathrm{GCE}$, as shown in Fig. 13. As shown in Fig. 13, no significant signals can be observed for interfering species such as $0.1 \mu \mathrm{M}$ of fructose, $0.1 \mu \mathrm{M}$ of sucrose, $0.1 \mu \mathrm{M}$ ureic acid (UA) and $0.1 \mu \mathrm{M}$ of ascorbic acid (AA)., while the addition of $1 \mu \mathrm{M}$ of glucose the oxidation peak current on $\mathrm{C} 6 \mathrm{P} / \mathrm{GCE}$ increases from 3.52 to $4.44 \mu \mathrm{A}$. This indicates that $\mathrm{C} 6 \mathrm{P} /$ GCE exhibit good selectivity towards glucose sensing. Hence, it is clear that the composite electrode has low sensitivity for the interfering species such as fructose, sucrose, uric acid and ascorbic acid.

The C6P modified GC electrode was exhibit a relatively wide linear range, low detection limit, high sensitivity, good selectivity and stability. The proposed polymer assisted C6P nanocomposite based non-enzymatic glucose sensor may have potential for the analysis of glucose in real samples. A performance comparison of our sensor with other nonenzymatic glucose sensors is summarized in Table 1. 
The repeatability and storage stability of glucose sensor were also evaluated at the same modified electrode over consecutive 30 days. When the modified electrode is not used, it is stored in air. After two weeks, the current reply of C6P modified electrode just losses $1.1 \%$ of its original current. The good reproducibility and long term stability of $\mathrm{CuO} / \mathrm{PEG} / \mathrm{GC}$ electrode are owing to the chemically stable $\mathrm{CuO}$ phase intercalated with PEG network. Thus, the observed actions of the proposed glucose sensor using $\mathrm{CuO} / \mathrm{PEG}$ nanocomposite showed a good selective response for the detection of glucose.

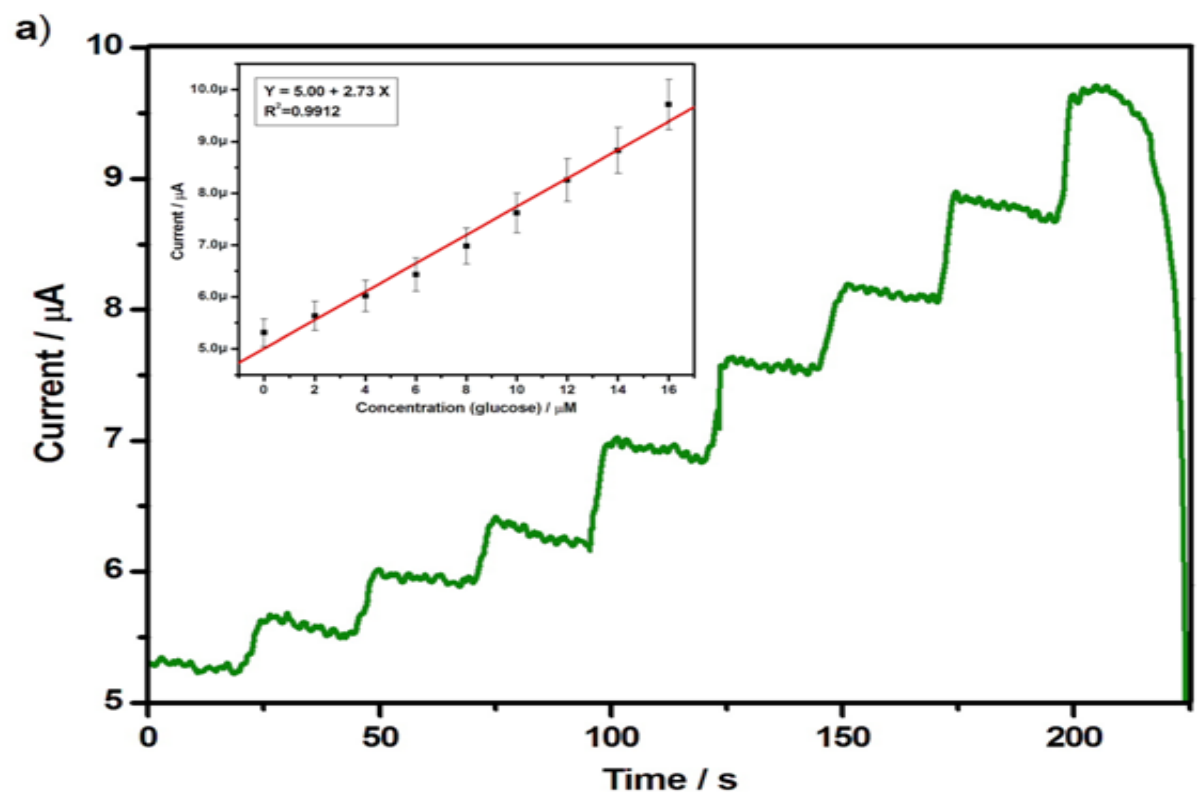

Fig. 10. Amperometric response of C6P modified GCE biosensor with the successive addition of each $2 \mu \mathrm{M}$ glucose in $0.1 \mathrm{M}$ of $\mathrm{NaOH}$ measured at $+0.40 \mathrm{~V}$. Insets: Corresponding calibration curve between the current and concentration of glucose.

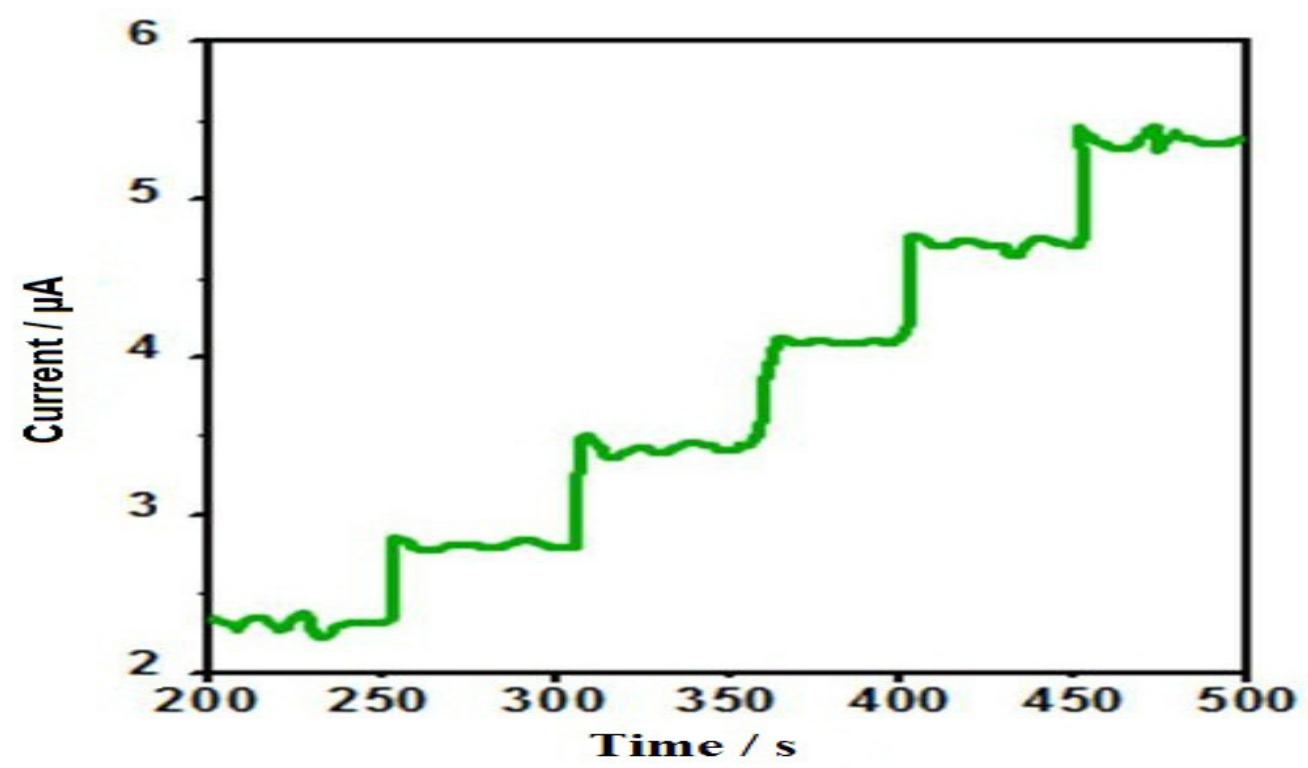

Fig. 11. Amperometric response of C6P modified GCE biosensor with the range of 20 to $100 \mu \mathrm{M}$ glucose in $0.1 \mathrm{M}$ of $\mathrm{NaOH}$, Eapp $=+0.40 \mathrm{~V}$. 


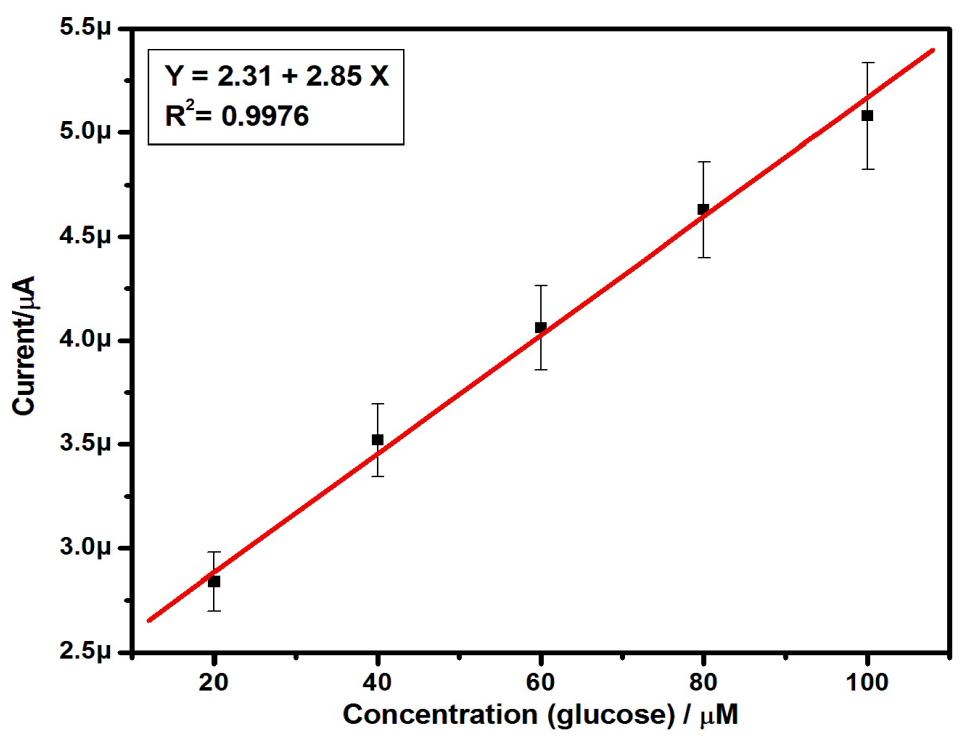

Fig. 12. Calibration curve between the current and concentration of glucose for amperometric response in the range of 20 to $100 \mu \mathrm{M}$.

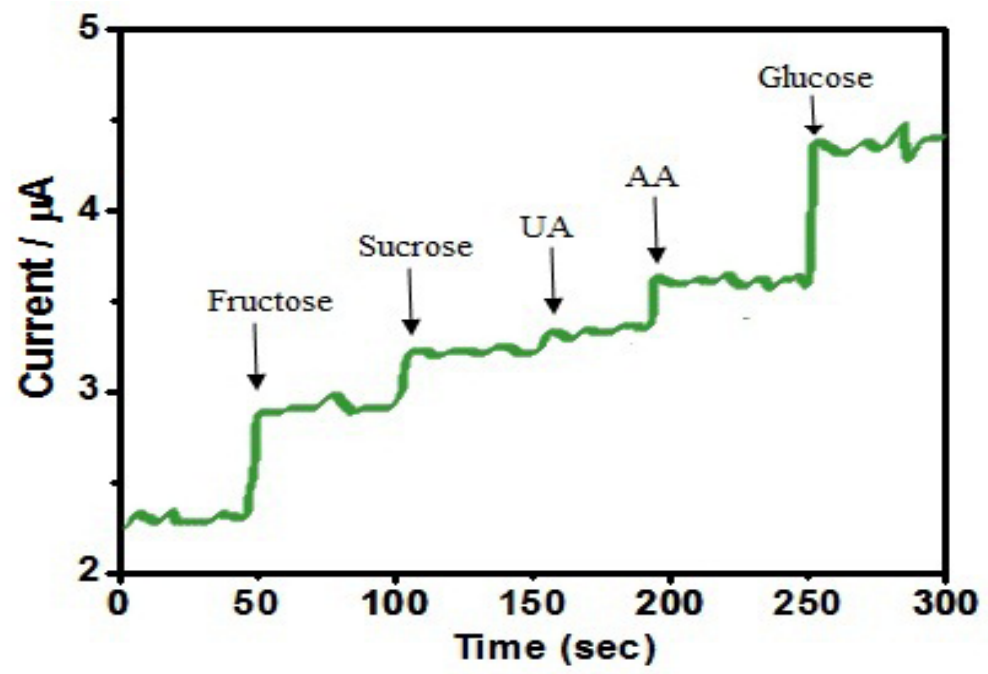

Fig. 13. Interference analysis of the sensor in $0.1 \mathrm{M} \mathrm{NaOH}$ at $+0.40 \mathrm{~V}$ with $1 \mu \mathrm{M}$ glucose and other interferents including $0.1 \mu \mathrm{M}$ of fructose, $0.1 \mu \mathrm{M}$ of sucrose, $0.1 \mu \mathrm{M}$ ureic acid (UA) and $0.1 \mu \mathrm{M}$ of ascorbic acid (AA).

TABLE 1. Comparison of some bio sensing activity of other modified electrodes with CuO/PEG/GCE.

\begin{tabular}{ccccc}
\hline S. No & Working electrode & Detection limit & Linear range & References \\
\hline 1 & Pd- SMNT & $0.2 \pm 0.05 \mu \mathrm{M}$ & $0.5-17 \mathrm{mM}$ & {$[32]$} \\
2 & $\mathrm{CuO}$ nanowires & $4.9 \mu \mathrm{M}$ & $0.0004-200 \mathrm{mM}$ & {$[33]$} \\
3 & Porous $\mathrm{Au}$ & $5 \mu \mathrm{M}$ & $2-10 \mathrm{mM}$ & {$[34]$} \\
4 & $\mathrm{Cu} / \mathrm{MWCNT}$ & $0.00021 \mathrm{mM}$ & $0.0007-3.5 \mathrm{mM}$ & {$[35]$} \\
5 & $\mathrm{Ni}-\mathrm{Cu} / \mathrm{TiO}_{2}$ nanotubes & $5 \mu \mathrm{M}$ & $3.2 \mathrm{mM}-10 \mu \mathrm{M}$ & {$[36]$} \\
6 & $\mathrm{CuO} / \mathrm{PEG} / \mathrm{GCE}$ & $0.25 \mu \mathrm{M}$ & up to $100 \mu \mathrm{M}$ & This work \\
\hline
\end{tabular}

Egypt.J.Chem. 62, No. 3 (2019) 


\section{Conclusion}

We have successfully synthesized copper oxide NMO through co-precipitation method. The synthesized $\mathrm{CuO}$ NMO was modified by using PEG as a capping or surfactant. The UV-vis-DRS show the optical conductivity of synthesized nanocomposites. The powder XRD investigation confirmed that the sample prepared with and without PEG in monoclinic structure corresponding to $\mathrm{CuO}$. The SEM image of C6P shows that the formation of nanorods. The HRTEM and SAED images show that, the petals like structure and good dispersion of crystallite $\mathrm{CuO} \mathrm{NMO}$ within the polymer matrix. The EDX spectrum confirms the presence of $\mathrm{Cu}$ and $\mathrm{O}$. The BET results exhibit that the modified NMO possess high surface area due to mesoporus. The C6P/GCE exhibited high electrocatalytic activity in the direction of the oxidation of glucose. The proposed method for glucose determination revealed that higher sensitivity and lower detection limit of $0.25 \mu \mathrm{M}(\mathrm{S} / \mathrm{N}=3)$ with a sensitivity of $113.8 \mu \mathrm{A} \mathrm{mM}^{-1} \mathrm{~cm}^{-2}$. The main reasons are the large surface area and good electrocatalytic activity of C6P nanocomposites, the polymer PEG enhanced the efficiency of the electron transfer between the modified electrode and glucose. The $\mathrm{CuO} / \mathrm{PEG} / \mathrm{GCE}$ also showed high stability, excellent selectivity and cost effective.

\section{References}

1. Wang J., Carbon- nanotubes based electrochemical biosensor: A review. Electroanalysis, 17, 7-47 (2005).

2. Rivas G.A., Rubianes M.D., Rodriguez M.D., Ferreyra N.F., Luque G.L., Pedano M.L., Miscoria S.A., Carbon nanotubes paste electrodes. A new alternative for the development of electrochemical sensor, Electroanalysis 19, 823-831 (2007).

3. Wang J., Electrochemical glucose biosensor, Chem. Rev. 108, 814-825 (2008).

4. Qiu C.C., Wang X., Liu, Hou S.F., Ma H.Y., Direct electrochemistry of glucose oxidase immobilized on nanostructured gold thin films and its application to bioelectrochemical glucose sensor, Electrochim. Acta 67, 140-146 (2012).

5. Zeng J., Wei W., Liu X., Wang Y., Luo G., A simple method to fabricate a prussian blue nanoparticles/ carbon nanotubes/ poly (1,2- diaminobenzene) based glucose biosensor, Microchim. Acta 160,
261- 267 (2008).

6. Umar A., Rahman M.M., Hajry A.A., Hahn Y.B., Enzymatic glucose biosensor based on flowershaped copper oxide nanostructures composed of thin nanosheets, Electrochem. Commun. 11, 278281 (2009)

7. Clark L.C., and Lyons C., Electrode system for continuous monitoring in cardiovascular surgery, Ann. N.Y. Acad. Sci. 102, 29-45 (1962).

8. Park S., Boo H., Chung T.D., Electrochemical non-enzymatic glucose sensors, Anal. Chim. Acta 556, 46-57 (2006).

9. Tsai T.W., Heckert G., Neves L.F., Tan Y.Q., Kao D.Y., Harrison R.G., Resasco D.E., Schimidtke D.W., Adsorption of gluxose oxidase onto singlewalled carbon nanotubes and its application in layer-by-layer biosensors, Anal. Chem. 81, 7917 7925 (2009).

10. Kalita G., Matsushima M., Uchida H., Wakita K., Umeno M., Graphene constructed carbon thin films as transparent electrodes for solar cell applications, J. Mater. Chem. 20, 9713-9717 (2010).

11. Reitz E., Jia W.Z., Gentile M., Wang Y., Lei Y., $\mathrm{CuO}$ nanospheres based nonenzymatic glucose sensor, Electroanalysis 20, 2482-2486 (2008).

12. Wang X., Hu C., Liu H., Du G., He X., Xi Y., Synthesis of $\mathrm{CuO}$ nanostructures and their application for nonenzymatic glucose sensing, Sens. Actuator B: Chem. 144, 220-225 (2010).

13. Chen A., and Chatterjee S., Nanomaterials based electrochemical sensor for biomedical applications, Chem. Soc. Rev. 42, 5425-5438 (2013).

14. Bobacka J., Ivaska A., Lewenstam A., Potentiometric ion sensors based on conducting polymers, Electroanalysis 15, 366-374 (2003).

15. Adhikari B., and Majumdar S., Polymers in sensor applications, Prog. Polym. Sci. 29, 699-766 (2004).

16. Kohler N., Sun C., Fichtenholtz A., Gunn J., Fang C., Zhang M.Q., Methotrexate-immobilized poly(ethylene glycol) magnetic nanoparticles for MR imaging and drug delivery, Small 2, 785-792 (2006).

17. Lee H.Y., Lee S.H., Xu C., Xie J., Lee J.H., Wu B., Koh A.L., Wang X., Sinclair R., Wang S.X., Nishimura D.G., Biswal S., Sun S., Cho S.H., Chen X., Synthesis and characterization of PVP-coated large core iron oxide nanoparticles 
as an MRI contrast agent, Nanotechnology 19, 165101/1-165101/6 (2008)

18. Hariharan R., Senthilkumar S., Suganthi A., Rajarajan M., Photodynamic action of curcumin derived polymer modified $\mathrm{ZnO}$ nanocomposites, Mater. Res. Bull. 94, 454-459 (2005).

19. Mo X., Wang C.Y., You M., Zhu Y.R., Chen Z.Y., $\mathrm{Hu}$ Y., A novel ultraviolet- irradiation route to CdS nano crystallites with different morphologies, Mater. Res. Bull. 36, 2277-2282 (2001).

20. Chen M., Xie Y., Chen H., Qiao Z., Zhu Y., Qian Y., Templated synthesis of CdS/PAN composites nanowires under ambient conditions, J. Colloid Interf. Sci. 229, 217-221 (2000).

21. Tian K., Prestgard M., Tiwari A., A review of recent advances in nonenzymatic glucose sensors, Mater. Sci. Eng. C 41, 100-118 (2014).

22. Deepa M., Kar M., Singh D.P., Srivastava A.K., Ahamed S., Influence of polyethylene glycol template on micro structure and electrochromic properties of tungsten oxide, Sol. Energy Mater. Sol. Cells 92, 170-178 (2008).

23. Sudha R., Senthilkumar S., Hariharan R., Suganthi A., Rajarajan M., Synthesis, characterization and study of photocatalytic activity of surface modified $\mathrm{ZnO}$ nanoparticles by PEG capping, J. Sol-gel Sci. Technol. 65, 301-310 (2013).

24. Reddy C.V.S., Jr E.H.W., Wen C., Mho S.I., Hydrothermal synthesis of $\mathrm{MoO}_{3}$ nanobelts utilizing poly(ethylene glycol), J. Power Sources 183, 330-333 (2008).

25. Wolcott A., Kuykendall T.R., Chen W., Chen S., Zhang J.Z., Synthesis and characterization of ultrathin $\mathrm{WO}_{3}$ nanodisks utilizing long-chain poly(ethylene glycol), J. Phys. Chem. B 110, 25288-25296 (2006).

26. Wang W., Zhan Y., Wang G., One-step solid state reaction to the synthesis of copper oxide nanorods in the presence of a suitable surfactant, Chem. Commun. 8, 727-728 (2001).

27. Ghanbari K., Babaei Z., Fabrication and characterization of non-enzymatic glucose sensor based on ternary $\mathrm{NiO} / \mathrm{CuO} /$ Polyaniline nanocomposites, Anal. Biochem. 498, 37-46 (2016).

28. Hariharan R., Senthilkumar S., Suganthi A., Rajarajan M., Synthesis and characterization of doxorubicin modified $\mathrm{ZnO} / \mathrm{PEG}$ nanomaterials and its photodynamic action, J. Photochem. Photobiol. B 116, 56-65 (2012).

29. Wang X., Liu E., Zhang X., Non-enzymatic glucose biosensor based on copper oxide-reduced graphene oxide nanocomposites synthesized from water-isopropanol solution, Electrochim. Acta, 130, 253-260 (2014).

30. Zhao D., Wan Y., Zhou W., Ordered Mesoporous Materials, Wiley Publication 55-116 (2013).

31. Ensafi A.A, Abarghoui M.M., Rezaei B., A new non-enzymatic glucose sensor based on copper/ porous silicon nanocomposite, Electrochim. Acta, 123, 219-226 (2014).

32. Meng L., Jin J., Yang G.X., Lu T.H., Zhang H., Cai C.X., Nonenzymatic electrochemical detection of glucose based on palladium- single walled carbon nanotube hybrid nanostructures, Anal. Chem. 81, 7271- 7280 (2009).

33. Zhuang Z.J., Su X.D., Yuan H.Y., Sun Q., Xiao D., Choi M.M., An improved sensitive nonenzymatic glucose sensor based on a $\mathrm{CuO}$ nanowire modified $\mathrm{Cu}$ electrode, Analyst 133, 126-132 (2008).

34. Li Y., Song Y.Y., Yang C., Xia X.H., Hydrogen bubble dynamic template synthesis of porous gold for nonenzymatic electrochemical detection of glucose, Electrochem. Commun. 9, 981-988 (2007).

35. Kang X.H., Mai Z.B., Zou X.Y., A sensitive nonenzymatic glucose sensor in alkaline media with a copper nanocluster/multiwall carbon nanotube-modified glassy carbon electrode. Anal. Biochem. 363, 143-150 (2007).

36. Li X., Yao J., Liu F., He H., Zhou M., Mao N., Xiaoa P., Zhang Y., Nickel/Copper nanoparticles modified $\mathrm{TiO}_{2}$ nanotubes for non-enzymatic glucose biosensors, Sens. Actuators B 181, 501508 (2013).

(Received 16/10/2018; accepted $20 / 11 / 2018$ ) 